\title{
Film Pendek Animasi 3 Dimensi Sejarah Masuknya Injil di Galela
}

\author{
Josten Van Her Sadouw ${ }^{1}$, Arie S. M. Lumenta ${ }^{2}$, Benerfit Narasiang ${ }^{3}$ \\ Email : vansadouw@gmail.com ${ }^{1}$ al@unsrat.ac.id ${ }^{2}$, benefitsemuel@gmail.com \\ Teknik Elektro Universitas Sam Ratulangi Manado, Jl. Kampus Bahu-Unsrat Manado, 95115
}

\begin{abstract}
ABSTRAK-- Galela adalah sebuah wilayah yang terletak pesisir pantai bagian utara pulau Halmahera di Kabupaten Halmahera Utara Provinsi Maluku Utara, dan letaknya sangat strategis karena berada di bibir laut Pasifik. Galela merupakan wilaya penginjilan dari Hendrik Van Dijken sejak tahun 1866, peran dari Hendrik Van Dijken ini sangat berpengaruh terhadap kekristenan di tanah Galela namun seiring berjalannya waktu keberadaan dan pemberitaannya mulai dilupakan dalam lingkungan masyarakat Kristen.

Begitu pesatnya perkembangan teknologi yang mencakup segala bidang, salah satunya dalam bidang Multimedia seperti animasi dapat dimanfaatkan untuk mengatasi permasalahan tersebut. Terdapat 3 tahap pembuatan Film Pendek Animasi 3 Dimensi diawali dengan tahap pra produksi, produksi, hingga pasca produksi. Pembuatan Film Pendek Animasi 3 Dimensi ini mengunakan tools Blender 2.71, Makehuman 1.1, dan Vegas Pro 15.117.

Dengan penggunaan Multimedia, penyampaian informasi akan menjadi lebih menarik dan mempermudah pengguna dalam mendapat informasi. Berdasarkan tujuannya, penelitian ini berhasil menampilkan dan menceritakan bagaimana sejarah masunya injil ditanah Galela dalam bentuk Film Pendek Animasi 3 Dimensi. Film Pendek Animasi 3 Dimensi ini dapat menjadi media untuk memperlajari sejarah masuknya inil di Galela.
\end{abstract}

Kata kunci - Animasi 3 Dimensi, Blender, Galela, Hendrik Van Dijken, Makehuman, Vegas Pro.

Galela is an area located on the northern coast of Halmahera Island in North Halmahera Regency of North Maluku Province, and is strategically located on the Pacific Rim. Galela was location servicing of
Hendrik Van Dijken's ministry since year 1866, the role of Hendrik Van Dijken greatly influenced Christianity in the land of Galela, but over time existence and preaching began to be forgotten in the Christian community in Galela.

Once the rapid development of technology covering all areas, one of them in the field of Multimedia such as animation can be used to solve problems. There are 3 stages of making Short Film 3 Dimension Animation starting with pre-production stage, production, until post production. Creating 3 Dimensional Short Animation Movies using Blender 2.71, Makehuman 1.1, and Vegas Pro 15,117 tools.

With the use of Multimedia, sending information will become more interesting and easier for users in getting information. Based on its purpose, this research successfully shows and tells how the history of the gospel in Galela land in the form of Short Film 3 Dimensional Animation. This 3 Dimensional Short Animation Movie can be a medium to learn the history of this inner entrance in Galela.

Keywords - 3 Dimensional Animations, Blender, Galela, Hendrik Van Dijken, Makehuman, Vegas Pro.

\section{PENDAHULUAN}

Pesatnya perkembangan teknologi yang mencakup segala bidang, salah satunya dalam bidang Multimedia seperti animasi mengalami perkemangan yang didukung dengan peralatan komputer yang sangat menunjang dalam pembuatan film animasi yang menarik. Perkembangan industri kreatif pada bidang animasi terus berkembang. Menurut Dirjen industri kecil dan menegah (IKM) Kamenperin Gati Wibawanigsih (2016), saat ini banyak tumbuh industri berbasis teknologi digital 
atau multimedia seperti animasi yang banyak dikerjakan oleh anak muda. Perkembangan industri animasi ini sudah semakin meluas dan makin banyak animator-animator Indonesia yang handal dalam membuat Film. Perkembangan Film Animasi saat ini sudah sesuai kebutuhan penggunanya, tidak semata untuk hiburan melainkan untuk promosi pelaku usaha maupun penyampaian informasi dikalangan pemerintah dan suwasta. Animasi merupakan teknik yang banyak dipakai di dalam dunia film sekarang ini, baik sebagai suatu kesatuan yang utuh atau bagian dari suatu film.

Galela adalah sebuah wilayah yang terletak pesisir pantai bagian utara pulau Halmahera di Kabupaten Halmahera Utara Provinsi Maluku Utara, dan letaknya sangat strategis karena berada di bibir laut Pasifik, yang memisahkan dengan pulau Morotai yang juga diapit oleh dua wilayah yaitu Kecamatan Tobelo dan Kecamatan Loloda, dengan batas wilayahnya adalah sebagai berikut: Sebelah Utara berbatasan dengan kecamatan Loloda, sebelah Selatan berbatasan dengan kecamatan Tobelo, sebelah Timur dengan Laut Pasifik dan Pulau Morotai, sebelah Barat dengan Kecamatan Ibu.

Pada tahun 1866 injil masuk ditanah Galela melalui penginjil Hendrik Van Dijken dan dua orang temannya yaitu Klassen dan De Bode. Sebelum masuknya injil penduduk setempat menganut agama islam dan sebagian menganut agama suku, injil mulai diterima oleh penduduk setempat setelah persitiwa hujan yang menenggelamkan seluruh pemukiman warga, 179 orang menerima injil dan menjadi Kristen pada tahun 1900. Kemudian berkembang sampai saat ini. Berdasarkan data statistik GMIH (Gereja Masehi Injili di Halmahera) tahun 2012 jumlah pemeluk agama kristen di Galela sebanyak 6.125 warga dari 19 jemaat tidak termasuk jemaat diluar pelayanan GMIH.

Peran seorang Hendrik Van Dijken sangat berpengaruh terhadap kekristenan ditanah Galela namun seiring berjalanya waktu keberadaan dan pemberitaanya mulai dilupakan dalam lingkungan masyarakat kristen contohnya pada matapelajaran agama Kristen kurang bahkan tidak diceritakan bagaimana sejarah permulaan Injil masuk ditanah Galela baik SD, SMP, SMA dan dalam Sekolah minggu, bahkan dalam monumen penginjilan Hendrik Van Dijken pun tidak ada penjelasan secara terperinci.

Oleh karena itu pembuatan film pendek animasi 3 dimensi sejarah masuknya injil di Galela dibuat untuk menceritakan bagaimana sejarah permulaan masuknya injil ditanah Galela dengan harapan dapat membantu menceritakan dan memberikan gambaran atau ilustrasi kepada setiap penonton tentang sejarah masuknya injil di Galela.
Berdasarkan penjelasan permasalaan di atas Maka, penulis mengangkat judul "Film Pendek Animasi 3 Dimensi Sejarah Masuknya Injil di Galela”.

\section{LANDASAN TEORI}

\section{A. Multimedia}

Multimedia adalah penggunaan computer untuk menyajikan dan mengabungkan teks, suara, ganbar, animasi danvideo dengan alat bantu (tool) koneksi (link) sehingga penguna dapat bernavigasi, berinteraksi, berkarya dan berkomunikasi (Hofstetter, 2001). Multimedia sering digunakan dalam dunia hiburan. Selain dari dunia hiburan, multimedia juga diadobsi oleh dunia game. Multimedia juga dapat diartika sebagai penggunaan beberapa media yang berbeda dalam menyampaikan informasi berbentuk text, audio, grafik, animasi, dan video. Menurut Binanto (2010), ada tiga jenis multimedia, yaitu : multimedia interaktif, hiperaktif, dan linier.

1). Multimedia Interaktif : pengguna dapat mengontrol apa dan kapan elemen-elemen multimedia akan dikirimkan atau ditampilkan.

2). Mutimedia Hiperaktif : Multimedia jenis ini mempunyai suatu struktur dari elemen-elemen terkait dengan pengguna yang dapat mengarahkannya. Dapat dikatakan bahwa multimedia jenis ini mempunyai banyak tautan (link) yang menghubungkan elemen-elemen multimedia yang ada.

3). Multimedia Liniear : Pengguna hanya menjadi penoton dan menikmati produk multimedia yang disajikan dari awal hingga akhir. Berdasarkan defenisi tersebut, multimedia dapat digambarkan seperti pada gambar 1

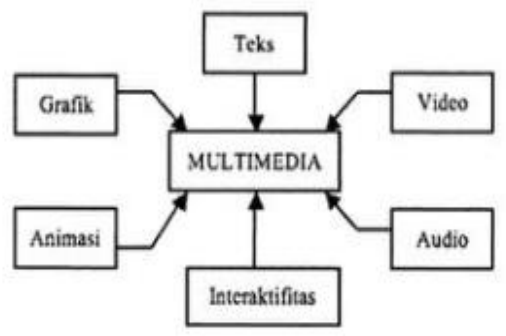

Gambar 1. Defenisi Multimedia (Vaughan, 2004)

\section{B. Film Pendek}

Menurut Heru Efendy, Durasi Film Pendek biasanya dibawah 60 menit. Dibanyak Negara seperti Jerman, Australia, Kanada dan Amerika Serikat, film cerita pendek dijadikan laboratorium eksperiment 
dan batu loncatan bagi seseorang atau sekelompok orang untuk kemudian memproduksi film cerita panjang. Jenis film ini banyak dihasilkan oleh para mahasiswa jurusan film atau orang atau sekelompok orang yang menyukai dunia film dan ingin berlatih membuat film dengan baik.

Pada hakikatnya film pendek bukan merupakan reduksi dari film dengan cerita panjang, atau sebagai wahana pelatihan bagi pemula yang baru masuk kedunia perfilman. Film pendek memiliki ciri/karakteristik sendiri yang membuatnya berbeda dengan film cerita panjang, bukan karena sempit dalam pemaknaan atau pembuatannya lebih mudah serta anggaran yang minim. Tapi karena film pendek memberikan ruang gerak ekspresi yang lebih leluasa untuk para pemainnya.

\section{Animasi}

Pengertian Animasi Menurut Ibiz Fernandes dalam bukunya Macromedia Flash Animation dan Cartooning: A creative Guide, animasi didefenisikan sebagai berikut : "Animation is the process of recording and playing back a sequence of stills to achieve the illusion of continues motion" (Ibiz Fernandes McGrawHill/Osborn, California, 2002). Yang artinya adalah : “Animasi adalah sebuah proses merekam dan memainkan kembali serangkaian gambar statis untuk mendapatkan sebuah ilusi pergerakan." Berdasarkan arti harafiah, Animasi adalah menghidupkan, yaitu usaha untuk menggerakkan sesuatu yang tidak bisa bergerak sendiri. Secara garis besar, animasi komputer dibagi menjadi dua kategori, yaitu: 1). Computer Assisted Animation, animasi pada kategori ini biasanya menunjuk pada sistem animasi 2 dimensi, yaitu mengkomputerisasi proses animasi tradisional yang menggunakan gambaran tangan. Komputer digunakan untuk pewarnaan, penerapan virtual kamera dan penataan data yang digunakan dalam sebuah animasi.

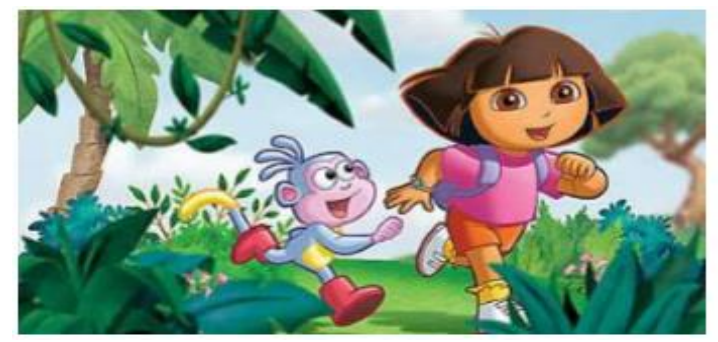

Gambar 2. Contoh Animasi 2 Dimensi dari Animasi Dora.

2). Computer Generated Animation, pada kategori ini biasanya digunakan untuk animasi 3 dimensi dengan program 3D seperti 3D Studio Max, Maya, Autocad, Blender dan lain-lain. Contoh animasi 3 dimensi Hendrik Van Dijken diambil dari Film Pendek Animasi 3 Dimensi Sejarah Masuknya Injil di Galela, seperti dibawah ini :

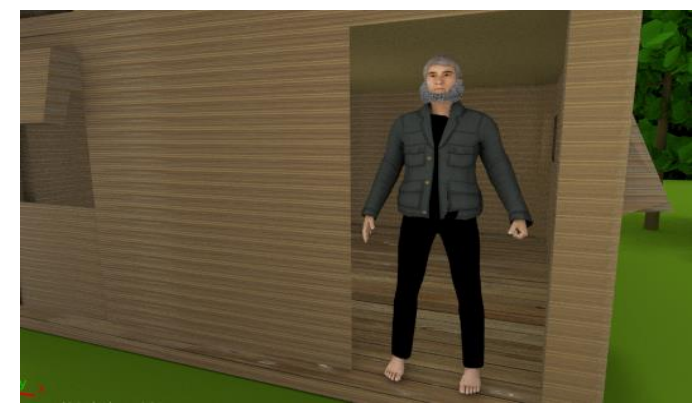

Gambar 3. Contoh Animasi 3 Dimensi Hendrik Van Dijken

\section{Sejarah}

Secara umum, Pengertian Sejarah merupakan ilmu pengetahuan yang membahas tentang segala peristiwa yang telah terjadi pada masa lampau. Dalam arti luas, Pengertian Sejarah merupakan ilmu yang mempelajari kejadian atau peristiwa pada masa lampau dalam kehidupan manusia melalui bukti tertulis misalnya kitab atau dokumen kuno dan lisan misalnya tradisi turun temurun dan mitos, bukti berupa benda-benda misalnya artefak dan prasasti serta monumen sejarah.

\section{E. Galela}

Galela adalah sebuah wilayah yang terletak pesisir pantai bagian utara pulau Halmahera di Kabupaten Halmahera Utara Provinsi Maluku Utara, dan letaknya sangat strategis karena berada di bibir laut Pasifik, yang memisahkan dengan pulau Morotai yang juga diapit oleh dua wilayah yaitu Kecamatan Tobelo dan Kecamatan Loloda, dengan batas wilayahnya adalah sebagai berikut: Sebelah Utara berbatasan dengan kecamatan Loloda, sebelah Selatan berbatasan dengan kecamatan Tobelo, sebelah Timur dengan Laut Pasifik dan pulau Morotai, sebelah Barat dengan Kecamatan Ibu.

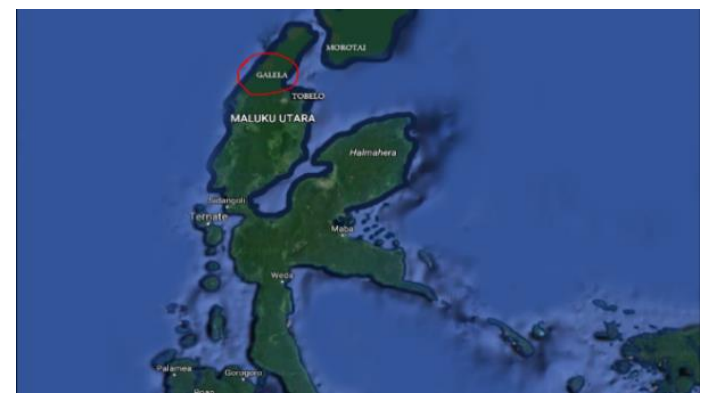

Gambar 4. Tampilan Peta Galela dari Google Maps 


\section{F. Alur Sejarah}

Berdasarkan buku Bahtera Injil di Halmahera penulis Pdt.M.Th Magany halaman 72-78 Pada tanggal 19 april 1866 Hendrik Van Dijken bersama dua orang penginjil yaitu Klaassen dan De Bode tiba di Galela setelah mendapat izin dari Sultan Ternate. Menurut isi surat dari Sultan Ternate mereka ditempatkan di Soa-sio, tanah pasisir pantai di Galela yang penduduknya memeluk agama islam agar penduduk setempat muda mengawasi mereka.

Tetapi karena Hendrik Van Dijken gemar bertani, ia mencari sebuah lokasi dipedalaman Galela yang bertempat disekitar danau yang tanahnya subur. Kemudian penduduk sekitar danau menunjukan tempat yang bernama Tomadoa yang artinya tempat raksasa. Maka pindahlah Van Dijken ke Tomadoa. Kemudian membangun Rumahnya disitu dan ia menamai Duma, yang di ambilnya dari Alkitab yesaya 21:11 yang artinya tempat keteduhan. Menurut etimologi Bahasa Galela, Duma berarti cuma atau melainkan. Dari nama desa inilah muncul peribahasa, "Duma una wi doohawa" yang berarti cuma atau hanya dia saja yang tidak diapa-apakan oleh raksasa itu. Di Duma inilah ia memulai pekerjaan pekabaran Injil. Sedikit demi sedikit hutan di daerah tersebut dibersihkan sehingga tempat itu disebut Zendingserf artinya pekarangan Zending. Van Dijken mulai mengarap tanah untuk ditanami tanaman palawija. Kemudian ditanami juga tembakau, coklat dan kopi. Langkah-langkah ini dilakukan Van Dijken sebagai langka pendekatan terhadap penduduk setempat. Hendrik Van Dijken dibantu Molli yang pernah bekerja pada pendeta Ottow selama di papua. Van Dijken menikahi pembantu pribadinya Soenpiet penduduk asli dari Galela karena istrinya yang menyusul dari Belanda meninggal dunia di Surabaya sebelum tibah di Galela. Penduduk setempat tidak berani mendekati mereka ataupun menolong mereka mengolah kebun karena penduduk setempat mengangap orang putih itu bersetan dan setan yang memberi bantuan sehingga tidak dibinasahkan oleh raksasa di Tomadoa itu. Lambat-laun penduduk mulai mendekati keluarga para pekabar injil itu, namun bukan Karena didorang untuk mendengarkan injil tetapi mengharapkan pertolongan berupa uang dan obat-obatan.

Pada tanggal 14-16 desember 1871 hujan lebat turun sehingga air danau meluap dan kampungkampung sekitar danau tergenang air. Selama tiga hari hujan turun dengan derasnya dan air danau makin meluap sehingga tergenanglah seluruh kampung sekitar danau kecuali rumah Van Dijken yang berada di dataran tinggi. Penduduk setepat menjadi takut dan mencari perlindungan pada orang kulit putih yang di anggaap bersetan karena rumahnya tidak tergenang air. Masalah ini di manfaatkan Hendrik Van Dijken untuk memberitakan injil, Hendrik Van Dijken mulai berbicara dengan mereka di ajaknya mereka berdoa bersama-sama kemudian hujan berhenti pada hari ke empat, air danau mulai surut dan kembali seperti semula.

Peristiwa ini di pandang penduduk setempat sebagai suatu kuasa dari dewa orang kulit putih sehingga sejumlah 26 orang menyerahkan diri menerima agama Kristen. Mereka pun menyerahkan anak-anak mereka untuk menerima pelajaran sekolah minggu. hingga di bangunyalah geraja mula-mula didesa duma pada tanggal 19 juni 1899. istri Van Dijken ibu Soenpiet membantu pekerjaan disekolah ia menerjemahkan doa-doa singkat dan nyayiannyayian gereja sambil mengajar murid-murid.

Peristiwa hujan itu juga mengerahkan orangorang beragama suku datang menyerahkan diri menjadi Kristen tetapi juga sejumlah 14 orang islam beralih ke agama Kristen. Peristiwa ini membuka jalan baru untuk perluasan pekabaran injil dari kampung duma kesebuah kampung soakonora salah satu kampung di Galela .

Pada Tahun 1871 Van Dijken ditabiskan sebagai pendeta di ternaten oleh pendeta Hoveker, predikan kota Ternate. Seiring berjalannya waktu pekabaran injil mulai meluas di tanah Galela meski mengalami bebagai halangan dan pengawasan dari kesultanan Ternate. Pekabaran injil mulai di buka di beberapa daerah Galela yaitu Soakonora ,dan kampung Lalonga sampai Limau sebuah kampung yang ada di pasisir Galela meski pun kurang berjalan dengan baik .

Hendrik Van Dijiken meningggal dunia pada tanggal 17 juni 1900, Setelah bekerja 36 tahun di Galela dan sempat merayakan 25 tahun berdirinya jemaat Duma pada tanggal 19 juli 1899. jumlah jiwa yang menganut agama Kristen pada saat Hendrik Van Dijken meninggal dunia adalah 179 orang khususnya didesa Duma.

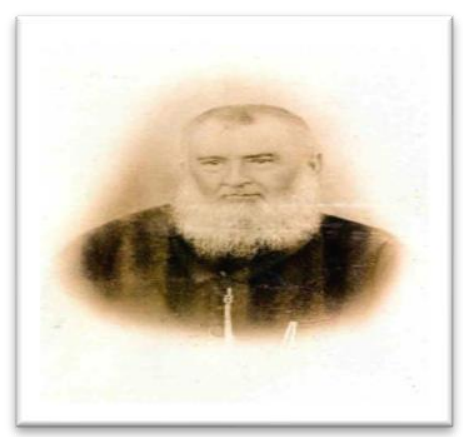

Gambar 5. Dukumentasi Foto Hendrik Van Dijken 
E-jurnal Teknik Informatika Vol 14, No.1 (2018) ISSN: 2301-8364

\section{METODOLOGI PERANCANGAN}

Pada metode atau langka-langka yang digunakan dalam perancangan Film Animasi ini menggunakan metode Development yang terdapat tiga tahap pembuatan yaitu : Tahap Pra-Produksi, Tahap Produksi, dan Tahap Pasca Produksi, seperti pada 6 :

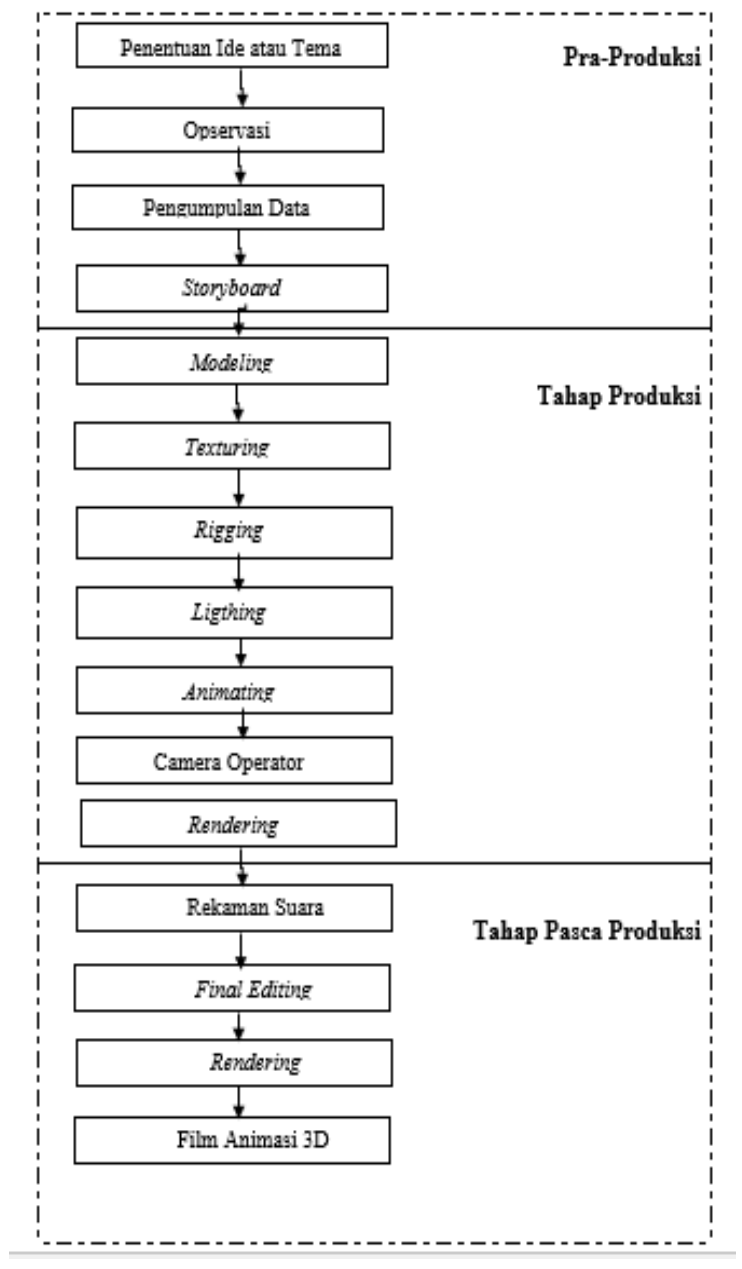

Gambar 6. Langkah-Langkah Perancangan Film Animasi 3D

\section{A. Tahap Pra-Produksi}

Tahap Pra-Produksi terdiri atas empat fase yaitu : Penentuan Ide atau Tema, opservasi, pengumpulan data, dan storyboard.

Penentuan Ide atau tema : Penentuan ide dan Tema merupakan tahap dimana penulis menentukan ide dan tema dari hasil survei pada lokasi monumen bersejarah Hendrik Van Dijken di desa Duma Galela Barat seperti pada gambar 3.4 sampai gambar 3.8.
1). Dan hasil konsultasi dengan beberapa dosen sehingga menjadi judul Film Pendek Animasi 3 Dimensi Sejarah Masuknya Injil di Galela.

2).Observasi : merupakan metode pengumpulan data dengan mengamati lokasi bersejarah dan monumen penginjil Hendrik Van Dijken di Galela desa Duma yang dilakukan pada tanggal 16 september 2016.

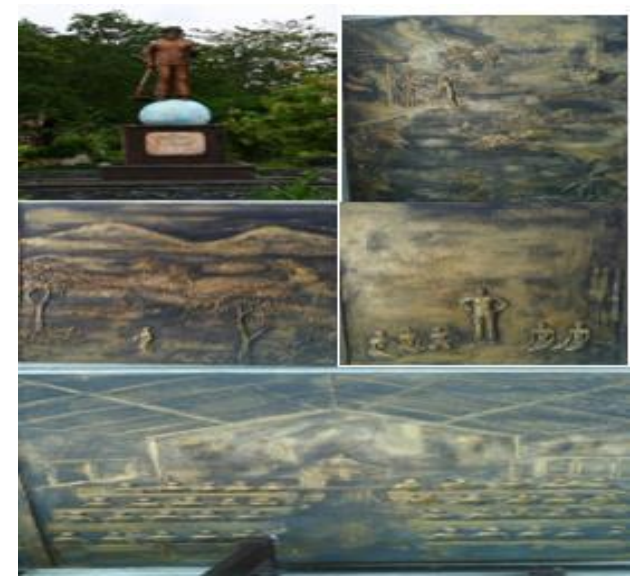

Gambar 6. Hasil observasi

3).Pengumpulan Data : Pada tahap ini penulis melakukan pengumpulan data-data pendukung yang akan digunakan dalam pembuatan film animasi, dengan cara penyebaran koisioner dan studi literature :

a. Kuisioner : merupakan metode pengumpulan data dengan cara penulis menyediakan pertanyaan yang telah disediakan kepada masyarakat Galela yang sering berektifitas menggunakan media online. Pemberian kuisioner telah dilakukan pada 17 April 2017.

b.Studi Literatur : Dalam penelitian ini penulis melakukan pengumpulan data dengan media buku yang ditulis oleh Pdt.M.Th Mangan tahun 2012. "Bahtera Injil Di Halmahera" penerbit BumgGmih dengan Institut Handrik Van Dijken, yang diambil oleh penulis dalam buku ini adalah garisgaris besar sejarah masuknya inil di Galela.

Dalam penelitian ini juga penulis menggunakan paper riset, jurnal, atau pun penelitian-penelitian sebelumnya yang berhubungan dengan topik animasi 3D diantaranya penelitian Bentelu Alan Stevenres. 2016."Animasi 3 Dimensi Pencegahan Cyber Crime(studi Kasus; Kota Manado)", (Skripsi). Universitas Sam Ratulangi Fakultas Teknik Program Studi Teknik Informatika Manado dalam penelitiannya peneliti mengambil contoh metode penelitian atau metode pengembangan animasi yang menggunakan tiga tahap yaitu : pra produksi, produksi, dan pasca produksi. 
Paramitha Apriliana Indah. 2014. “Animasi 3D Kisah Ayu Intan Permani”.'(Skripsi). Sekolah Tinggi Manejemen Informatika Dan Komputer STMIK Amikom Purwokerto. Purwokerto, dan Wibawa Cahya Budi. 2011. "Pembuatan Film Animasi 3D Anak Berjudul Ayo Kita Shalat", Sekolah Tinggi

Manejemen Informatika Dan Komputer STMIK Amikom Yogyakarta. Selain itu juga data yang diperlukan berasal dari sumber lain, seperti internet.

4).Storyboard : Pada tahap ini penulis mulai melakukan pembuatan storyboard untuk mempermudah penulis dalam proses produksi Film Pendek Animasi 3 Dimensi Sejarah Masuknya Injil di Galela berdasarkan buku Bahtera injil di Halmahera, seperti pada gambar 7 .

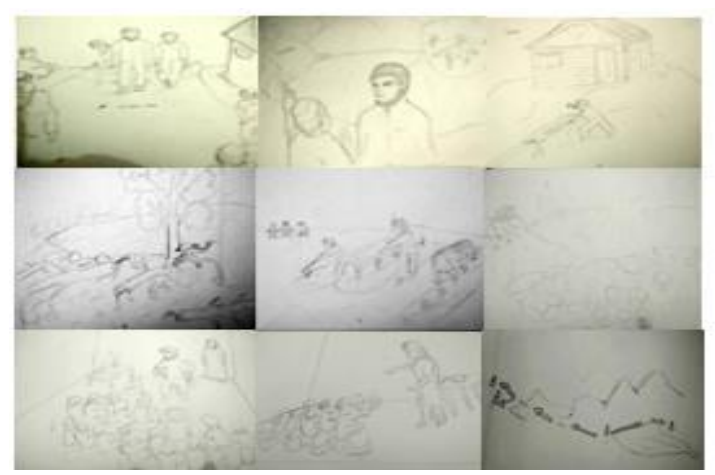

Gambar 7. Storyboard Film Animasi

\section{HASIL DAN PEMBAHASAN}

\section{A..Modeling}

\section{1) Modeling Objek Manusia Pada Makehuman}

Pada perancangan dan pembuatan film pendek animasi 3 dimensi sejarah masuknya injil di Galela objek manusia dibuat mengunakan aplikasi makehuman kemudian diolah sesuai dengan kebutuhan megunakan tools modeling, geometries, dan materials. Kemudian objek manusia yang telah dibuat di expor pada aplikasi blender dengan menggunakan addons MHX2.

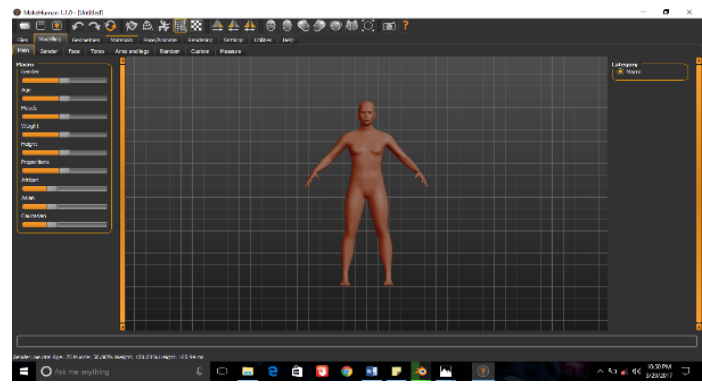

Gambar 8. Objek Human Standar sebagai dasar modeling karakter manusia

\section{2) Modeling Objek Pada Blender}

Pada perancangan dan pembuatan objek lainnya serta penyempurnaan objek atau karakter manusia dilakukan pada Blender memakai objek Cube, $U V$ Sphare, Plane, add tree, images as planes dan Cylinder.

Kemudian proses pembentukan model objek dilakukan pada edit mode dengan bantuan fungsi ekstrude, skala, dan grab dan beberapa tool editor seperti subdivision surface sehingga terbentuklah model objek sesuai dengan keinginan penulis. Model objek yang dibuat dan diolah pada blender di antaranya :

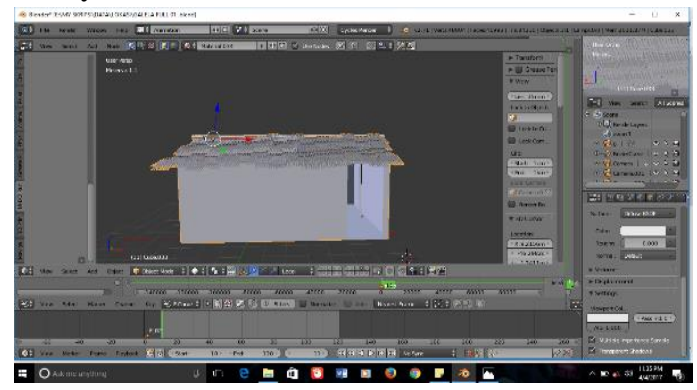

Gambar 9. Proses modeling rumah warga

\section{B.. Teksturing}

Pada proses teksturing ini penulis menabahakan tekstur atau warna yang sesuai dengan objek aslinya sehingga terlihat lebih natural dan menarik.Proses teksturing dalam aplikasi blender dapat dibuat dengan menggunakan tools material yang ada pada kolom properties dan $U V$ map pada aplikasi blender, Teksturing objek yang telah dibuat oleh penulis Seperti gambar dibawa ini:

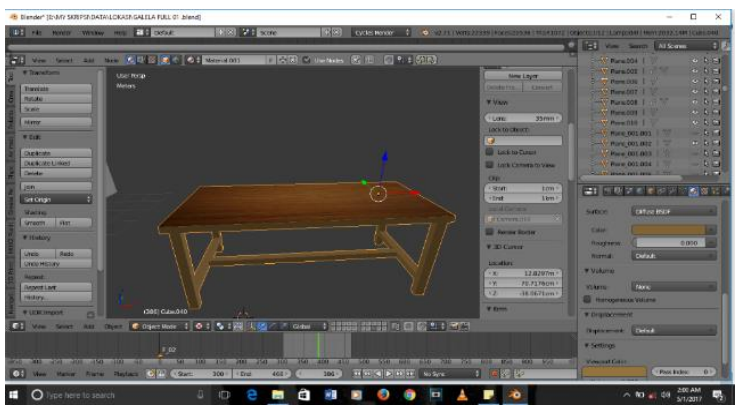

Gambar 10. Proses Texturing meja

\section{Riging}

Pada tahap riging ini penulis tidak melakukan proses pemasangan tulang karakter manusia secara manual pada aplikasi blender karena setiap karakter yang di inport dari makehuman telah dilakukan riging atau pemberian tulang, penulis hanya perlu mengaktifkan fungsi dari MHX2 Runtime yang ada 
E-jurnal Teknik Informatika Vol 14, No.1 (2018) ISSN: 2301-8364

pada blender sesuai dengan kebutuhan penulis untuk mengontrol gerakan dari karakter, dan karakter siap dianimasikan. Seperti pada gambar 11 penulis mengaktifkan fungsi Mhx2 Runtime pada karakter Hendrik Van Dijken untuk mengontrol pergerakannya. Hal yang sama penulis lakukan pada karakter manusia lainnya.

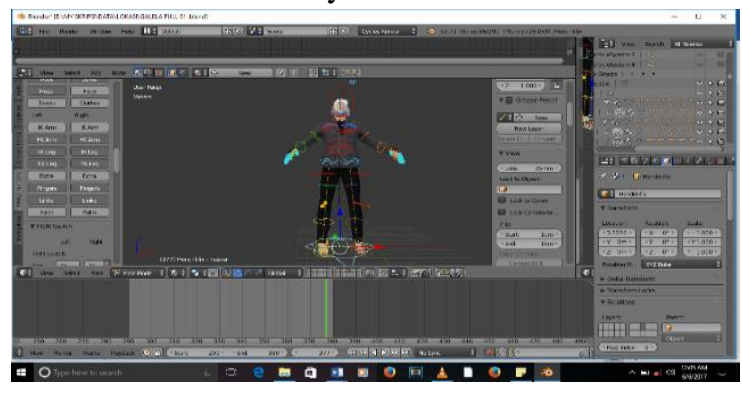

Gambar 11. Proses Pengaktifkan Fungsi Mhx2 pada Krakter.

\section{Lighting}

Pada tahap Lighting penulis melakukan proses pemberian cahaya pada model sehingga diperoleh kesan visual yang realistis. Lamp atau lampu terdapat beberapa macam diantaranya yaitu point, hemi dan sun. Namun pada tidak semua part penulis melakukan pemberian cahaya menggunakan Lamp. Hanya pada part tertentu saja. Karena penulis telah menggunakan World Editor penggunaan efek world dengan setinggan note editor yang diseuaikan akan memberikan pencahayaan yang mirip bola bumi. Seperti pada gambar 12 .

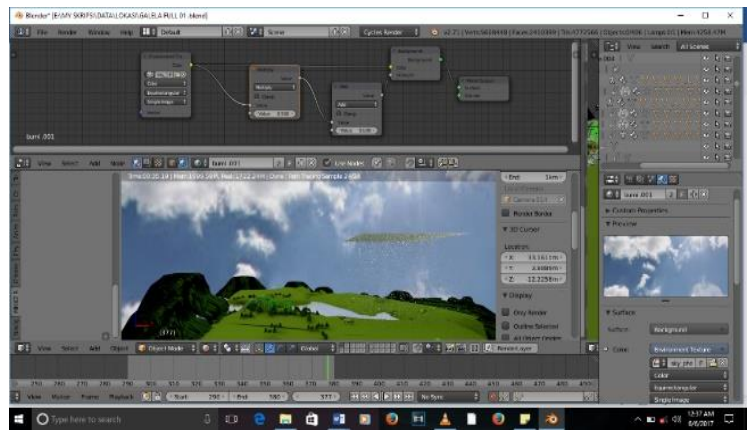

Gambar 12. Pengaturan Ligthing World.

\section{E.Animating}

Pada tahap Animating ini penulis melakukan pengaturan objek animasi dengan memberikan gerakan pada objek maupun pada kamera sesuai storyboard. Untuk melakukan animasi ini penulis melakukan secara manual sesuai dengan storyboard yang telah dibuat oleh penulis.

Mengatur pergerakan karakter tokoh Hendrik dan kedua temannya saat tiba di Galela desa soasio yang sesuai kebutuhan storyboard dari film pendek animasi 3 dimensi sejarah masuknya injil di Galela. Seperti pada gambar 13 .

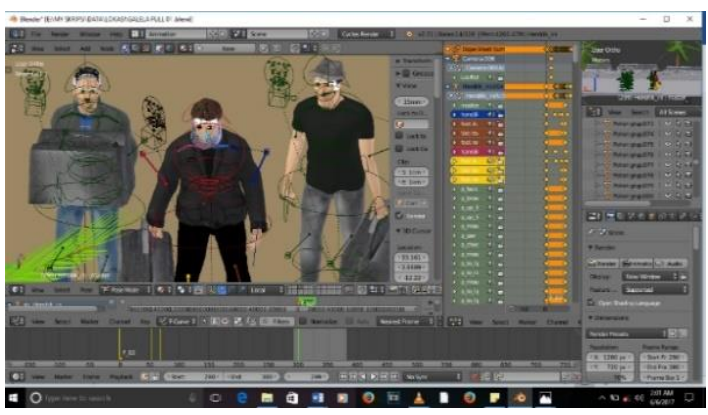

Gambar 13. Proses Animating Tokoh Tiba di Soasio.

\section{F. Camera Operation}

Pada tahap Camera Operation ini penulis melakukan pengoperasian kamera masih pada tools animasttion agar dapat melihat pergerakan objek manusia dan merekam objek yang telah dianimasikan oleh penulis, seperti pada gambar 14 .

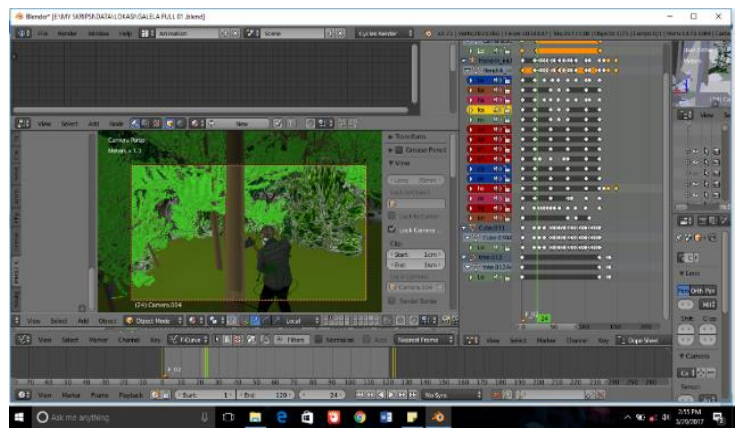

Gambar 14. Camera Operasi Untuk Part Hendrik Menebang Pohon.

\section{G. Rendering}

Pada tahap Rendering ini dilakukan untuk membuat animasi kedalam bentuk film pendek 3 dimensi. Proses rendering dilakukan pada setiap adengan satu persatu sehingga menjadi beberapa bagian film pendek animasi 3 dimensi sejarah masuknya injil di Galela. Proses rendering dilakukan pada tools render yang terdapat pada kolom properties dengan menekan tombol animation.

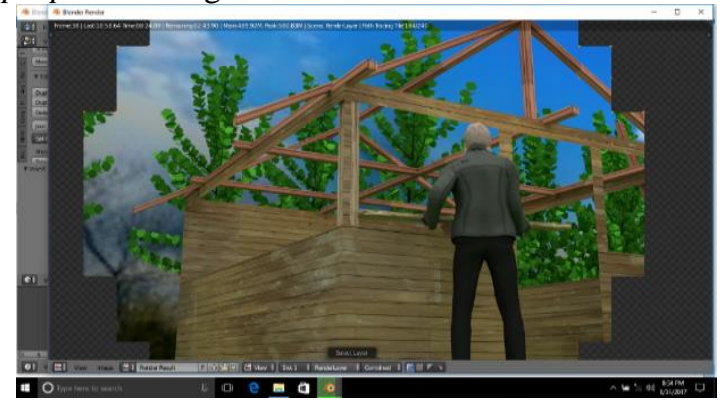


Gambar 15. Render Part Membangun Gereja Mulamula

\section{H. Final Editing}

Final Editing merupakan proses dimana semua file film 3 dimensi hasil render pada aplikasi Blender dan file audio yang dibuat pada aplikasi vegas recorder kemudian diimport pada aplikasi Vegas pro, seperti pada Gambar 16.

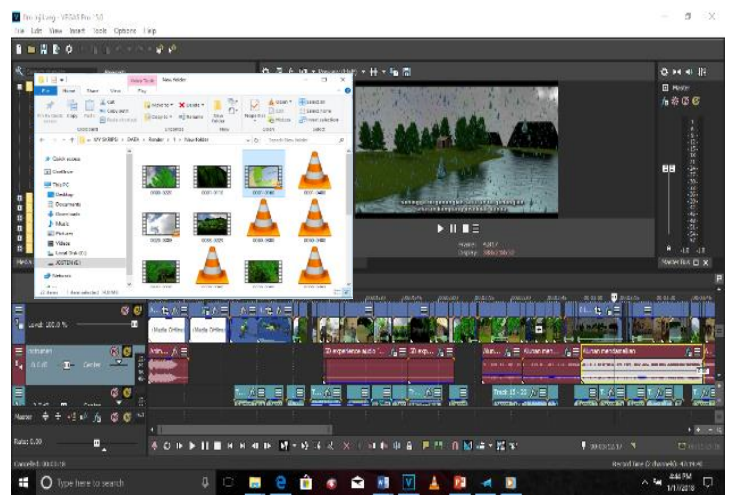

Gambar 16. Menggabungkan File-file Film, audio fx dan backround audio kedalam aplikasi Vegas Pro.

\section{Film Animasi}

Film Pendek Animasi merupakan hasil (output) setelah semua tahap selesai. Setelah melewati semua proses dari awal sampai akhir pembuatan Film Pendek Animasi 3 Dimensi Sejarah Masuknya Injil di Galela yang diawali dengan modeling pada aplikasi Makhuman dan Blender sampai dengan proses akhir yaitu rendering dengan mengunakan aplikasi Vegas Pro, akhirnya dapat menghasilkan Film Pendek Animasi 3 Dimensi dengan Format .MP4 beresolusi 1280x720 pixel durasi film selama 5.46 menit dan ukuran file 329 MB. Dapat dilihat opening film dimana menampilkan judul film, nama dan nim dari penulis Gambar 17. dibawa ini.

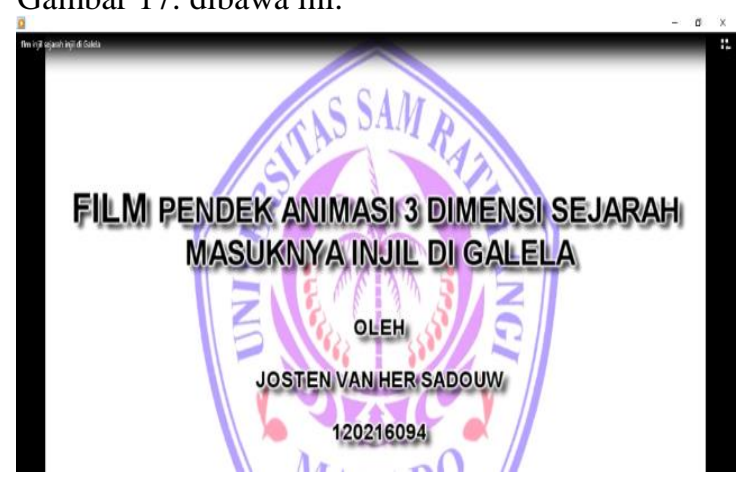

Gambar 17. Opening Film

\section{PENUTUP}

\section{A. Kesimpulan}

Pada pembuatan film pendek animasi 3 dimensi sejarah masuknya injil ditanah Gelela dapat diambil beberapa kesimpulan, antara lain :

1) Melalui penelitian ini sejarah masuknya injil di Galela dapat dibuat menjadi Film Pendek Animasi 3 Dimensi.

2) Penelitian ini dapat membantu memberikan gambaran bagaimana sejarah masuknya injil di Galela.

3) Penelitian ini dapat menimbulkan kesadaran masyarakat akan peran dari tokoh Hendrik Van Dijken terhadap kekristenan di Galela.

4) Film Pendek Animasi 3 Dimensi Sejarah Masuknya Injil di Galela muda dimengerti.

B. Saran

Diperlukan pemahaman mengenai perancangan, pemodelan, dan konsep yang baik serta penguasaan software yang digunakan. Untuk itu penulis memberikan saran sebagai berikut :

1) Dalam pembuatan film animasi 3 dimensi, pahami terlebih dahulu konsepnya supaya dalam pembuatannya berjalan dengan mudah.

2) Gunakanlah komputer yang kapasitasnya lebih besar dalam pembuatan film animasi karena akan mempercepat proses pemodelan, animasi, dan rendering.

3) Karena objek bawaan kareakter manusia dari mekehuman yang di export ke blander cukup besar 3 sampai $5 \mathrm{Mb}$, ada baiknya dalam setiap part cerita animasi jangan dibuat satu projek pada blender tetapi dibuat secara terpisa pada beberapa projek untuk menghindari terjadi masalah blender has stopped working karena terlalu banyak data yang ada pada projek.

\section{DAFTAR PUSTAKA}

[1] B.A Stevenres. Animasi 3 Dimensi Pencegahan Cyber Crime(studi Kasus; Kota Manado) Skripsi S.kom, Universitas Sam Ratulangi Fakultas Teknik Program Studi Teknik Informatika Manado. Manado 2016

[2] B.I. Multimedia Digital - Dasar Teori dan Pengembangannya. Penerbit Andi. Yogyakarta 2010,

[3] H.T.Fred Multimedia Literacy, $3^{\text {rd }}$ Ed. Irwan/McGraw-Hill, New York. 2001

[4] Munir. "Multimedi Konsep \& Aplikasi dalam Pendidikan”. Alfabet Cv Bandung. Bandung 2012 
E-jurnal Teknik Informatika Vol 14, No.1 (2018) ISSN: 2301-8364

[5] P.A Indah. "Animasi 3D Kisah Ayu Intan Permani”.(Skripsi). Sekolah Tinggi Manejemen Informatika Dan Komputer STMIK Amikom Purwokerto. Purwokerto 2014

[6] Pdt.M.Th Mangany. "Bahtera Injil Di Halmahera”. Bumg-Gmih dengan Institut Handrik Van Dijken 2012.

[7] W.C Budi. "Pembuatan Film Animasi 3D Anak Berjudul Ayo Kita Shalat", Skripsi. Sekolah Tinggi Manejemen Informatika Dan Komputer STMIK Amikom Yogyakarta. Yogyakarta 2011.

[8] Wahono S. Wismoady. 2001.’Disini Ku Temukan: Petunjuk Mempelajari dan mengajarkan Alkitab".Gunung Mulia. Jakarta

[9] T. Vaughan, Multimedia Making it work. Penerbit andi. Yogyakarta 2004.

[10] Familly Hendrik Van Dijken,[Online] tersedia di:http://www.vanbaarda.nl/familie/hendrik-vandijken/, [di akses 11/30/2016]

[11] Galela dan Letak Geografisnya [Online] tersedia di:http://portal-geografi.umbengkulu.web.id/id3/27682653/Galela 87432_portal-geografi-umbengkulu.html . [diakses : 13 april 2017]

[12] Hak Cipta dan Pengertian Makehuman, [Online] tersedia di: www.makehuman.org_[diakses : 14 Agustus 2016 ]

[13] Memahami Lebih Dalam Pengertian Animasi3d [Online] tersedia di: ,http://www.idseducation.com/articles/memaha mi-lebih-dalam-pengertian-animasi-3d/. [diakses: 15 Agustus 2017 ]

[14]NN. Perbedaan Animasi 2d dan Animasi 3d Pengertian Animasi dan Contoh [Online] tersedia di:http://iz-inside.blogspot.co.id/2016/10/ perbedaan- animasi-2d-dan- animasi-3d. html, [diakses: 15 Agustus 2017 ]

[15] NN.Pengertian Film Pendek, [Online] tersedia di:https://id.wikipedia.org/wiki/Film_pendek, [di akses : 30 November 2016]

[16]NN.Pengertian Sejarah dan Ruang Lingkup Ilmu Sejarah [Online] tersdia di:,http://hariannetral.com/2015/05/pengertiansejarah-dan-ruang-lingkup-ilmu-sejarah.html, [di akses : 30 November 2016]

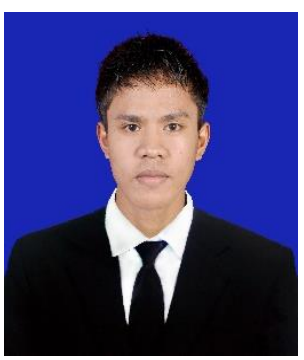

Saya bernama Josten Van Her Sadouw dan merupakan anak bungsu dari empat bersaudara, lahir di Soatobaru pada tanggal 10 januari 1993. Saya berasal dari Halmahera Utara. Saya mulai menempuh pendidikan di sekolah dasar SD GMIH Soatobaru. Kemudian melanjutkan studi tingkat pertama di SMP Kristen Galela dan selanjutnya saya menempuh pendidikan tingkat atas di SMA N 1 Halut. Setelah itu, di tahun 2012 saya melanjutkan pendidikan ke salah satu perguruan tinggi yang berada di Manado yaitu Universitas Sam Ratulangi Manado, dengan mengambil Program Studi S-1 Teknik Informatika di Jurusan Elektro Fakultas Teknik. Pada Tahun 2017 bulan Oktober tanggal 6 , penulis membuat Skripsi demi memenuhi syarat Sarjana (S1) dengan penelitian berjudul Film Pendek Animasi 3 Dimensi yang dibimbing oleh dua dosen pembimbing yaitu Arie S. M. Lumenta, ST., MT, dan Ir. Benerfit Narasiang, MT sehingga pada tanggal 22 Januari 2018 penulis resmi lulus di Teknik Informatika Universitas Sam Ratulangi Manado menyandang gelar sarjana komputer dengan predikat sangat memuaskan. 